\title{
A Kinetic and Equilibrium Study of Zinc Removal by Brazilian Bentonite Clay
}

\author{
Ana Lucia Pereira de Araujo ${ }^{\mathrm{a} *}$, Marcelino Luiz Gimenes , \\ Maria Angelica Simões Dornellas de Barros ${ }^{\mathrm{b}}$, Meuris Gurgel Carlos da Silva

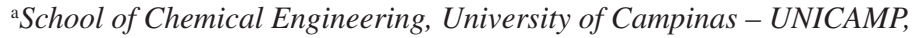 \\ CEP 13083-970, Campinas, SP, Brazil \\ ${ }^{\mathrm{b}}$ Departament of Chemical Engineering, State University of Maringá - UEM, \\ CEP 87020-900, Maringá, PR, Brazil
}

Received: May 16, 2012; Revised: August 19, 2012

\begin{abstract}
This paper aimed to study the removal of zinc using bentonite clay from the Northeastern Brazil, as an adsorbent. A study of the clay subjected to thermal and chemical treatment was performed in order to evaluate the optimization of the adsorption capacity of this material. For the evaluation of the kinetic equilibrium of the process, experimental tests were carried out in a finite bath system. The maximum amount of metal adsorbed was $0.151 \mathrm{mEq}$ of metal per gram of calcined clay and $0.257 \mathrm{mEq}$ of metal per gram of sodium saturated clay. The kinetic models of pseudo-first order, pseudo-second order and intraparticle diffusion were fitted to experimental data, and the pseudo-second order model provided the best result. The Langmuir and Freundlich models were used for the adsorption equilibrium analysis, and the Langmuir model provided the best fit for sorption isotherms. The physicochemical characterization of clay involved X-ray diffraction, scanning electron microscopy, chemical analysis by energy-dispersive $\mathrm{X}$-ray spectroscopy, helium pyconometry and thermogravimetric analysis. The modified clay has potential use for removing $\mathrm{Zn}^{2+}$ ions replacing more expensive adsorbents, since good adsorption properties will be also associated with great availability and low cost.
\end{abstract}

Keywords: X-ray diffraction, adsorption, zinc, Bofe clay

\section{Introduction}

Conventionally, the removal of heavy metals is by chemical precipitation, although this process is relatively simple and economical, generates a large volume of sludge and, depending on the metal and the chemical characteristics of the effluent after the final filtration, the effluent may still present residual metal values above the acceptable environmental conditions, requiring the application of a complementary process to the final polishing of the effluent.

The adsorption proved to be an alternative to tertiary treatment for the removal of heavy metals from aqueous solutions, because it is not only very efficient, but also economic, since it can use low-cost adsorbents. Alternative adsorbents such as natural clay have been assessed due to its high availability and cost-effectiveness for the removal of heavy metals. The use of clay as an adsorbent for removing heavy metals is due to its ion exchange capacity (CEC) in the range of 60 to $170 \mathrm{mEq} / 100 \mathrm{~g}$, selectivity, renewability and affordability compared with other natural and synthetic adsorbents. Due to their advantages, clay potentials as a heavy metal removal agent have been investigated by ${ }^{1-4}$, however, further studies are needed to assist in understanding the mechanisms and parameters involved in the process.

Arias and $\mathrm{Sen}^{5}$ studied the removal of $\mathrm{Zn}^{2+}$ ions in kaolin. The results show that Langmuir and Freundlich

*e-mail: araujo.pereira11@gmail.com equations both are applicable to describe the adsorption of zinc $\left(\mathrm{Zn}^{2+}\right)$ on kaolin within this small initial metal ion concentration range. Kubilay et al. ${ }^{6}$ studied the removal of copper (II), Zn (II) and Co (II) using a natural bentonite Clay was found that the efficient removal of these metals even at very low concentrations. The Langmuir isotherm model was fitted to the adsorption data and the order of affinity of metal ions with clay was $\mathrm{Zn}^{2+}>\mathrm{Cu}^{2+}>\mathrm{Co}^{2+}$.

Veli and Alyuz $z^{7}$ studied the removal of $\mathrm{Zn}^{2+}$ ions in natural bentonite clay. The removal of $\mathrm{Zn}^{2+}$ ions was $3.6 \mathrm{mg} \cdot \mathrm{g}^{-1}$ for the initial concentration of $20 \mathrm{mg} . \mathrm{L}^{-1}$. Abollino et al. ${ }^{8}$ studied the removal of $\mathrm{Zn}^{2+}$ ions in montmorillonite. The total capacity of $\mathrm{Zn}^{2+}$ in montmorillonite was $3.61 \mathrm{mg} \cdot \mathrm{g}^{-1}$. Tito et al. ${ }^{9}$ studied the zinc adsorption process by bentonite clay. The maximum retention capacity, $3.24 \mathrm{mg} . \mathrm{g}^{-1}$, was obtained in $\mathrm{pH} 4$ using particle size of bentonite clay $<0.5 \mathrm{~mm}$.

The clays can be modified in various ways, such as treatment with organic and inorganic acids and bases, and heat treatment, changing directly its physicochemical properties to improve its adsorption capacity, increasing thus, the potential applications in new technologies. Although a chemical modification can improve the adsorption of heavy metal ions, the cost of chemicals and methods of modification should also be considered. Since the modification of the adsorbent surface can also change its properties, it is recommended that studies on the physicochemical characterization must be done in 
order to achieve a better understanding of the mechanism of adsorption on modified materials.

According to Santos ${ }^{10}$, clays containing adsorbed water in the voids between the particles and the surface of the particles in the form of hydroxyl groups. This clay minerals ability to adsorb water is a problem in the adsorption of heavy metals in porous bed, due the clay expansion. The water can be eliminated by heating clay at temperatures above $300{ }^{\circ} \mathrm{C}$. In the case of montmorillonite water is intercalated between the layers that define the crystal structure and causes swelling or expansion of basal plane (001) to cause an increase in distance interplanar basal and can be eliminated at temperatures between $500{ }^{\circ} \mathrm{C}$ and $550{ }^{\circ} \mathrm{C}$.

The clay thermal treatment is needed, since after this process it undergoes dehydroxylation and modification in their structure, so as not expand in water, making it more favorable to the adsorption in porous bed.

Preliminary study with clay sodium aiming their potential use in removing heavy metal. Clays have a high cation excharge capacity, that is, cations within the crystalline lamellae can be exchanged for other cations present in aqueous solution, without thereby modifying their crystal structure. This exchange is possible chemically modify clays directly altering their physicochemical properties, improving their ability to adsorption and ion exchange by increasing its potential applications in new technologies.

This study employed a modified Bofe bentonite clays for the kinetic study of zinc in finite bath system. The influence of adsorbate concentration and temperature were investigated. Kinetic models were tested in order to identify the adsorption process mechanisms. The Langmuir and Freundlich models were applied for the analysis of the adsorption equilibrium. Thermodynamic parameters were evaluated as a function of the temperature. Several characterization techniques were employed in order to identify the changes in clay that may influence its applicability in adsorption process.

\section{Material and Methods}

\subsection{Adsorbent}

The Bofe bentonite clay from Boa Vista, Paraíba State, Brazil, was used as adsorbent. Initially, the material was crushed and classified to obtain an average particle diameter of $0.074 \mathrm{~mm}$. The cation exchange capacity of natural clay was $93.3 \pm 7 \mathrm{mEq} / 100 \mathrm{~g}$, determined by exchange with ammonium cations ${ }^{5}$. The natural clay was oven calcined at $500{ }^{\circ} \mathrm{C}$ for 24 hours. Sodium saturated clay was prepared by dispersing $10 \%$ of clay weight in water and adding $10 \mathrm{~mL}$ of $\mathrm{NaCl}(2.5 \mathrm{M})$, stirring $(500 \mathrm{rpm})$ and heating $\left(45^{\circ} \mathrm{C}\right)$ for 4 hours. The mixture was vacuum-filtered and washed with deionized water to remove excess sodium, until negative test with $1 \%$ silver nitrate solution. The pellets were oven dried at $100 \pm 5^{\circ} \mathrm{C}$ for 24 hours.

The point of zero charge of the adsorbents, $\mathrm{pHzpc}$, was determined by potentiometric titration, following the model described by Guarino et al. ${ }^{11}$. This model shows that charges on the surface of the solid result from an acid-base reaction (Surface Complexation Model). The experimental procedure consisted of titrating two suspensions containing $10 \mathrm{~g}$ of clay each, in $100 \mathrm{~mL}$ of $\mathrm{CH}_{3} \mathrm{COONH}_{4}(0.1 \mathrm{M})$ as supporting electrolyte (after waiting 10 minutes for stabilization), one containing $\mathrm{CH}_{3} \mathrm{COOH}(0.3 \mathrm{M})$ and another containing $\mathrm{NH}_{4} \mathrm{OH}(0.25 \mathrm{M})$. This titration was performed in a wide range of acid and base concentrations. The surface charge, $\mathrm{Q}$ in units of mol/g, was obtained by applying Equation 1 . The $\mathrm{pHzpc}$ value of the solid was obtained by constructing a graph of the total surface charge of the solid as a function of $\mathrm{pH}$. This value corresponds to the $\mathrm{pH}$ whereby the curve crosses the $\mathrm{x}$-axis $(\mathrm{Q}=0)$.

$Q=\frac{C_{a}-C_{b}+\left[\mathrm{OH}^{-}\right]-\left[H^{+}\right]}{C_{S}}$

Where $\mathrm{C}_{\mathrm{a}}$ and $\mathrm{C}_{\mathrm{b}}$ corrected acid and base concentrations (M), respectively; $\mathrm{C}_{\mathrm{s}}$ concentration of suspended solid $\left(\mathrm{g} . \mathrm{L}^{-1}\right)$

\subsection{Characterizing the adsorbent}

Natural, calcined and sodium saturated clays were submitted to X-ray diffraction (XRD) in Phillips equipment, X'Pert model, K $\alpha$ cooper radiation $(\lambda=1.5418 \AA$ ), observing the diffraction angle of $2 \theta$, step size of 0.02 degrees ranging between $4^{\circ}$ and $30^{\circ}$. In order to evaluate the adsorbent morphology, a scanning electron microscopy (SEM) with LEO equipment, LEO 440i, with $500 \mathrm{X}$ power was performed. Energy dispersive X-ray techniques (EDX) were used to identify the total chemical composition of the clay. The real density was determined by Micrometrics Accupyc 1330 helium gas pycnometer and the analyses were performed at $28{ }^{\circ} \mathrm{C}$ and $0.0010 \mathrm{psig} / \mathrm{min}$ equilibrium rate. The thermogravimetric analysis allowed establishing the relationship between physical and chemical properties and temperature. This analysis was carried out ranging from room temperature to $1000{ }^{\circ} \mathrm{C}$ in nitrogen atmosphere and using equipment Shimadzu, model TGA-50.

\subsection{Metal solution}

The aqueous solution was prepared from analytical grade hexahydrated zinc nitrate, $\mathrm{Zn}\left(\mathrm{NO}_{3}\right)_{2} \cdot 6 \mathrm{H}_{2} \mathrm{O}$. The metal concentration remaining in aqueous solutions submitted to zinc adsorption tests was determined by the Perkin-Elmer ANALYST-100 Atomic Absorption Spectrophotometer.

\subsection{Batch adsorption}

The tests were performed using $1.0 \mathrm{~g}$ of adsorbent and $100 \mathrm{~mL}$ of metal solution at initial concentration of $3.0 \mathrm{mEq} . \mathrm{L}^{-1}$ and $\mathrm{pH}$ value of 4.5 , which was defined according to metal speciation. The solution $\mathrm{pH}$ was adjusted by using $\mathrm{HNO}_{3}(0.1 \mathrm{M})$ or $\mathrm{NH}_{4} \mathrm{OH}(0.1 \mathrm{M})$ and measured with a $\mathrm{pH}$ meter (OAKTON).

The vials were kept at room temperature $\left(25^{\circ} \mathrm{C}\right)$ under constant stirring at $150 \mathrm{rpm}$ in a Shaker with control of temperature and agitation. At predetermined time intervals aliquots were withdrawn and the metal concentration was determined by atomic absorption spectrophotometer. The adsorption capacity of metal ion at each time step was calculated using the Equation 2:

$q_{e q}=\frac{V}{m_{s}}\left(C_{0}-C_{e q}\right)$ 
Where $\mathrm{q}_{\mathrm{eq}}$ adsorption capacity of metal ion $\left(\mathrm{mEq} \cdot \mathrm{g}^{-1}\right.$ ); $\mathrm{C}_{0}$ initial concentration of metal ion in solution (mEq. $\left.\mathrm{L}^{-1}\right)$; $\mathrm{C}_{\mathrm{eq}}$ final concentration of metal ion after the equilibrium is reached (mEq.L $\left.\mathrm{L}^{-1}\right)$; $\mathrm{V}$ volume of solution $(\mathrm{L}) ; \mathrm{m}_{\mathrm{s}}$ mass of adsorbent $(\mathrm{g})$.

The percentage of removal (\%Rem) was calculated by Equation 3:

$\% \operatorname{Rem}=\left(\frac{C_{0}-C_{e q}}{C_{0}}\right) \times 100$

The experimental data were fitted to kinetic models of pseudo-first order, pseudo-second order and intraparticle diffusion model. The fit was performed using the software Origin 6.0.

a) Pseudo-first order model (Equation 4):

$q_{t}=q_{e q}\left(1-e^{-a_{1} t}\right)$

Where $a_{1}$ pseudo-first order adsorption rate constant $\left(\min ^{-1}\right) ; q_{t}$ amount of metal ion absorbed at time $t\left(m E q . L^{-1}\right)$.

b) Pseudo-second order model (Equation 5):

$q_{t}=q_{e q} \frac{q_{e q} k t}{q_{e q}\left(a_{2} t\right)+1}$

Where $\mathrm{a}_{2}$ pseudo-second order adsorption rate constant, (g.(mEq min))

c) Intraparticle diffusion (Equation 6): $q_{t}=a_{3} t^{0.5}$

Where $\mathrm{a}_{3}$ intraparticle diffusion constant, $\left(\mathrm{min}^{-1}\right)$.

\subsubsection{Adsorption equilibrium}

The experiments were performed under the same conditions of the kinetic study, varying the concentration of adsorbate from $0.1 \mathrm{mEq} . \mathrm{L}^{-1}$ to $6 \mathrm{mEq} . \mathrm{L}^{-1}$ using the $\mathrm{pH}$ value set by the study of chemical speciation of ions, for an interaction time of 150 minutes. After reaching the equilibrium, aliquots were withdrawn to determine metal concentration. The adsorption capacity of metal ion was calculated using the Equation 2. The experimental data were fitted with Langmuir and Freundlich isotherms. The fitting was performed using software Origin 6.0.

Langmuir isotherm (Equation 7):

$q_{e q}=\frac{q_{m} b C_{e q}}{1+b C_{e q}}$

Where $\mathrm{q}_{\mathrm{m}}$ maximum amount of ion adsorbed per unit of adsorbent mass to form a complete monolayer on the surface, $\left(\mathrm{mEq} . \mathrm{g}^{-1}\right)$; b constant related to adsorption energy, corresponds to the affinity between adsorbent surface and solute, $\left(\mathrm{L} \cdot \mathrm{mEq}^{-1}\right)$.

The use of Langmuir isotherm in fitting the data to remove metal ions from synthetic solutions has been reported with good results ${ }^{12-16}$.

The essential characteristics of Langmuir isotherm can be expressed by the constant dimensionless number, separation factor or equilibrium parameter $\left(R_{L}\right)$, which indicates the curvature of the sorption isotherm: if $R_{L}>1$, the isotherm is not favorable; if $\mathrm{R}_{\mathrm{L}}=1$, it is linear; $0<\mathrm{R}_{\mathrm{L}}<1$, favorable; $R_{L}=0$, irreversible. This value is given by the Equation 8:

$$
R_{L}=\frac{1}{1+b C_{0}}
$$

Freundlich isotherm (Equation 9):

$$
q_{e q}=K_{f} \times C_{e q}{ }^{n}
$$

Where $\mathrm{k}_{\mathrm{f}}$ constant related to adsorbent capacity; $\mathrm{n}$ constant related to adsorption intensity.

\subsubsection{Thermodynamics of adsorption}

The Langmuir isotherm model was used to fit the equilibrium data obtained under the conditions used to study kinetics in finite bath at $293 \mathrm{~K}, 313 \mathrm{~K}, 323 \mathrm{~K}$ and $348 \mathrm{~K}$ using calcined Bofe clay as adsorbent to remove $\mathrm{Zn}^{2+}$. Thermodynamic parameters for the adsorption process, $\Delta \mathrm{H}, \Delta \mathrm{S}$ and $\Delta \mathrm{G}$ were calculated using the thermodynamic Equations 10 and 11:

$\Delta \mathrm{G}=-\mathrm{RT} \times \ln \mathrm{K}_{\mathrm{d}}$

$\ln \left(K_{d}\right)=-\frac{\Delta G}{R T}=\frac{\Delta S}{R}-\frac{\Delta H}{R T}$

Where R universal gas constant $\left(8.314 \times 10^{-3} \mathrm{~kJ} .(\mathrm{K} \mathrm{mol})^{-1}\right)$; $\mathrm{T}$ temperature, $\mathrm{K} ; \Delta \mathrm{H}$ enthalpy variation, $\left(\mathrm{kJ} \cdot \mathrm{mol}^{-1}\right) ; \Delta \mathrm{G} \mathrm{Gibbs}$ free energy variation $\left(\mathrm{kJ} . \mathrm{mol}^{-1}\right) ; \Delta \mathrm{S}$ entropy variation $\left(\mathrm{J} . \mathrm{Kmol}^{-1}\right) ; \mathrm{K}_{\mathrm{d}}$ coefficient of adsorbate distribution $\left(\mathrm{L}^{\mathrm{g}} \mathrm{g}^{-1}\right)$.

The $\ln \left(\mathrm{K}_{\mathrm{d}}\right)$ versus $1 / \mathrm{T}$ graph must be linear with the slope $(-\Delta H / R)$ and intercepts the $y$-axis in $(\Delta S / R)$, providing the values of $\Delta \mathrm{H}, \Delta \mathrm{S}$ and $\Delta \mathrm{G}$. The variation of Gibbs free energy $(\Delta \mathrm{G})$ is the fundamental criterion of spontaneity of the process. The given process only occurs spontaneously at a given temperature if $\Delta \mathrm{G}<0$. This relationship is valid when the enthalpy variation remains constant in the considered temperature range.

\section{Results}

\subsection{Adsorbent characterization}

\subsubsection{X-ray diffraction (XRD)}

The diffractograms for natural, calcined and sodium saturated Bofe clay are presented in Figure 1. There were peaks relating to the montmorillonite (M) and quartz (Q),

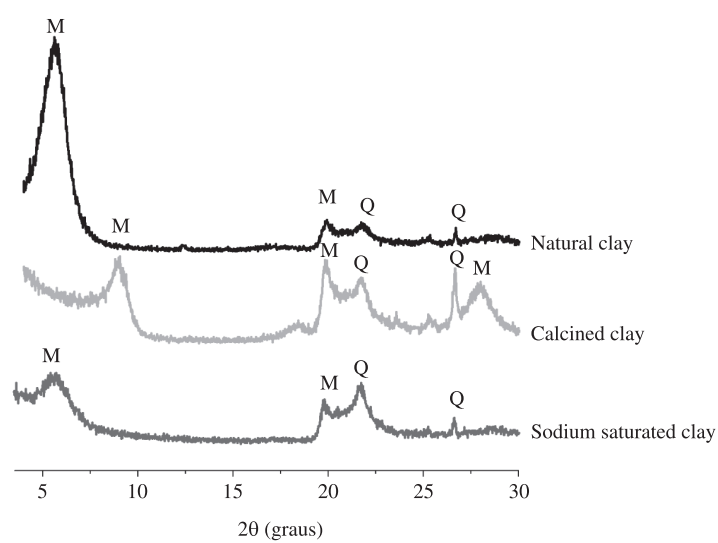

Figure 1. X-ray diffractograms of natural, calcined and sodium saturated clays. 
typical of this type of clay that has smectite as a predominant clay mineral ${ }^{17}$, moreover, these clays does not have a highly crystalline structure, since the peaks detected by the diffraction are not well-defined.

Heat and chemical treatment provided a modification in the clay structure, decreasing the intensity of the typical peak of montmorillonite (d001), indicating a possible distortion in the arrangement of tetrahedral and octahedral layers after these treatments. With the heat treatment there is a reduction in the basal spacing, whereas the chemical treatment increases this distance. The temperature causes thermal distortions of the crystalline structure, modifying thus the Bragg reflection standards. Dehydration and dehydroxylation occurring during calcination may be followed by cation movement within the octahedral sheet ${ }^{18-20}$. Structural and basal spacing changes caused by thermal treatment modify the hydration capacity of the clays, making them more stable in the presence of water, when compared to the natural sample. This enables it to be used in fixed bed columns, since it is a solution for natural clay expansion problems.

\subsubsection{Morphology and qualitative chemical composition}

The micrographs of natural, calcined and sodium saturated Bofe clays are shown in Figure 2. Comparing the micrographs, the particles have no defined format and present ripples that indicate stacking of the layers with much dispersed grains and variable dimensions, corroborating the information given by Santos ${ }^{20}$ for clays of this group. The morphology of the samples, regardless of the modification process, is very similar, without significant differences in the morphological structure after thermal or sodium treatment.

Chemical analysis from the energy-dispersive X-ray spectroscopy presented in Table 1 allowed evaluating qualitatively the components of the clays. There was a predominance of silicon and aluminum, base elements of the clays of smectite group, originating from the structure of the phyllosilicate. This clay is polycationic due to the presence of $\mathrm{Ca}^{2+}, \mathrm{Mg}^{2+}$ and $\mathrm{Na}^{+}$cations on the natural clay, which is interesting for the adsorption process. After calcination, there was no significant change in the chemical composition of Bofe clay and the exchangeable cations were preserved. With sodium treatment, there was a reduction in the amount of $\mathrm{Mg}^{2+}$ and $\mathrm{Ca}^{2+}$ and an increase in $\mathrm{Na}^{+}$, due to ion exchange during process.

\subsubsection{Particle density by He gas pycnometry}

The real density values of natural, calcined and sodium saturated Bofe clays are presented in Table 2. Thermal and sodium treatments led to a slight reduction in real density of the clay. In the first case, due to dehydration and dehydroxylation caused by calcination, whereas in the second case, the replacement of $\mathrm{Ca}^{2+}$ and $\mathrm{Mg}^{2+}$ by $\mathrm{Na}^{+}$, an element with lower density and larger ionic radius, resulted in a decrease in the mass/volume ratio.

\subsubsection{Thermogravimetric analysis}

Figure 3 shows the thermogravimetric derivative curve samples of natural, calcined and sodium saturated Bofe clays. All clays have a region of water loss, volatile compounds, microorganisms and organic matter, around $50{ }^{\circ} \mathrm{C}\left(\mathrm{P}_{1}\right)$. There are two types of losses: type I, water adsorbed with high mobility, being easily removed; and type II, hydration water around the exchangeable cations, whose presence depends on the number of hydrated cations in the interlayer space.Type II takes place in natural clays, with very hydratable cations such as $\mathrm{Na}^{+}, \mathrm{K}^{+}$and $\mathrm{Ca}^{2+[21]}$. Dehydroxylation regions $\left(\mathrm{P}_{2}\right)$ occur around $400{ }^{\circ} \mathrm{C}$ and $480{ }^{\circ} \mathrm{C}$. The range of structural hydroxyl loss for natural clay is in agreement with $\operatorname{Santos}^{20}$, i.e., $400{ }^{\circ} \mathrm{C}$ to $700{ }^{\circ} \mathrm{C}$. Based on this analysis, the temperature of $500{ }^{\circ} \mathrm{C}$ was set

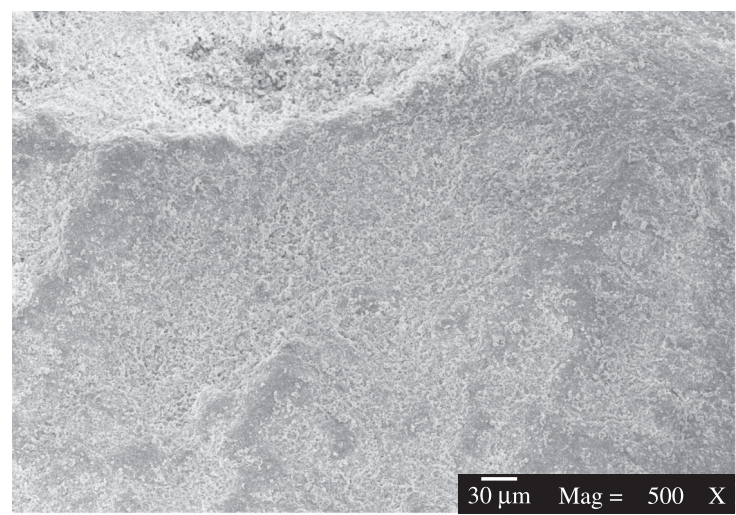

(a)

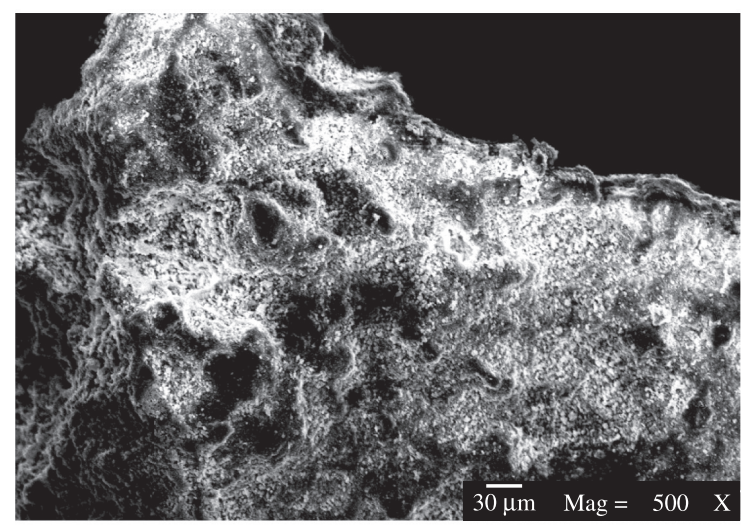

(b)

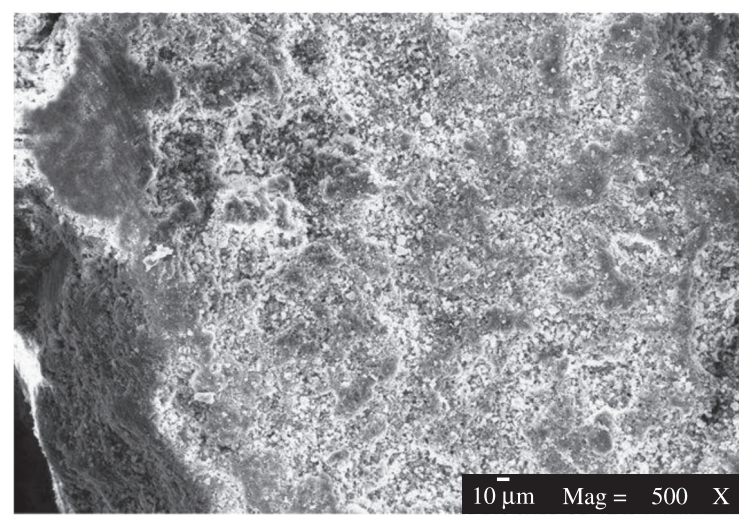

(c)

Figure 2. (a) Natural, (b) calcined and (c) sodium saturated clays micrographs (500× magnification). 
for clay calcination in order to increase its stability for subsequent application in fixed bed adsorption column. For sodium-saturated clay, besides $\left(\mathrm{P}_{1}\right)$ and $\left(\mathrm{P}_{2}\right)$ losses, there was a new stage of weight loss $\left(\mathrm{P}_{3}\right)$ regarding $\mathrm{NaCl}$, interspersed in the clay structure during sodium treatment. This peak reaches about $800{ }^{\circ} \mathrm{C}$, coinciding with the melting point of sodium chloride.

\subsection{Determination of the adsorbent point of zero charge and metal chemical speciation}

Figures 4 and 5 illustrate the charge variation for all clay samples and the ions $\mathrm{Zn}^{2+}$ speciation curve of the in aqueous solution with nitrate ions at $50 \mathrm{mg} . \mathrm{L}^{-1}$ determined using HYDRA.

The electrical charge of clay surfaces is dependent on $\mathrm{pH}$. There is a particular $\mathrm{pH}$ value where the amounts of positive and negative electric charges are equal, this $\mathrm{pH}$ value is characteristic for each clay and called point of zero charge, $\mathrm{pH}_{\mathrm{zpc}}$. The main surface functional groups in clays that generate loads are $\mathrm{pH}$-dependent $\mathrm{Si}-\mathrm{OH}$ groups and Al-OH. In Figure 4, the $\mathrm{pH}_{\mathrm{ZPC}}$ value for calcined clay is close to $\mathrm{pH} 5.3$, whereas for natural and sodium saturated clay is close to $\mathrm{pH}$ 6.0. This difference is because there are more hydroxyl groups on natural and sodium-saturated clays, while calcined clay underwent dehydroxylation. In order to maximize the removal of zinc ions from an aqueous solution, considering the ion behaves as a cation, it was defined that the adsorption process would be performed in a range of $\mathrm{Ph}>\mathrm{pH}_{\mathrm{ZPC}}$, and in these cases $\mathrm{pH}>5.3$ for calcined clay and $\mathrm{pH}>6.0$ for sodium saturated clay. However, taking into consideration the effect of $\mathrm{Zn}^{2+}$ precipitation under high $\mathrm{pH}$ values, a study of chemical speciation of these ions was carried out in relation to the $\mathrm{pH}$.

Table 1. Chemical analysis of natural, calcined and sodium saturated Bofe clays.

\begin{tabular}{cccc}
\hline $\begin{array}{c}\text { Components } \\
(\% \text { mass })\end{array}$ & Natural & Calcined & $\begin{array}{c}\text { Sodium } \\
\text { saturated }\end{array}$ \\
\hline $\mathrm{Na}$ & 0.54 & 0.50 & 1.83 \\
$\mathrm{Mg}$ & 1.34 & 1.19 & 1.15 \\
$\mathrm{Al}$ & 7.43 & 6.84 & 7.25 \\
$\mathrm{Si}$ & 46.86 & 46.17 & 45.95 \\
$\mathrm{~K}$ & $0.12^{*}$ & - & - \\
$\mathrm{Ca}$ & 0.44 & 0.58 & 0.12 \\
$\mathrm{Ti}$ & 0.42 & 0.53 & 0.47 \\
$\mathrm{Fe}$ & 3.58 & 3.32 & 3.52 \\
$\mathrm{Total}$ & 60.73 & 59.13 & 60.52 \\
\hline
\end{tabular}

* $\leq 2$ sigma

Table 2. Real density of natural, calcined and sodium saturated Bofe clays.

\begin{tabular}{lc}
\hline \multicolumn{1}{c}{ Bofe Clay } & Real density $\left(\mathbf{g . c m}^{-\mathbf{3}}\right)$ \\
\hline Natural & $2.5024 \pm 0.0038$ \\
Calcined & $2.4866 \pm 0.0031$ \\
Sodium saturated & $2.3648 \pm 0.0004$ \\
\hline
\end{tabular}

In Figure 5, the metal species present in deionized water are in the forms of $\mathrm{Zn}^{2+}, \mathrm{ZnOH}^{+}, \mathrm{Zn}(\mathrm{O})$ and $\mathrm{Zn}(\mathrm{OH})_{2(\mathrm{~S})}$. Within the $\mathrm{pH}$ range of 1.0-5.0, the solubility of the $\mathrm{Zn}(\mathrm{OH})_{2(\mathrm{~S})}$ is high and therefore, the $\mathrm{Zn}^{2+}$ is the main species in the solution. Within the $\mathrm{pH}$ range of 5.0-9.0 the solubility of $\mathrm{Zn}(\mathrm{OH})_{2(\mathrm{~S})}$ decreases and at $\mathrm{pH} 10.0$, the solubility of $\mathrm{Zn}(\mathrm{OH})_{2(\mathrm{~S})}$ is very low at this time, and the main species in the solution is $\mathrm{Zn}(\mathrm{OH})_{2(\mathrm{~S})}$ and the fraction of ions $\mathrm{Zn}^{2+}$ in aqueous solution decreases.

Through the analysis of $\mathrm{pH}_{\mathrm{ZPC}}$ (Figure 4) we should proceed the adsorption in a $\mathrm{pH}$ range $>\mathrm{pHzpc}$, in these cases, $\mathrm{pH}>5.3$ for the calcined clay and $\mathrm{pH}>6.0$ for sodium saturated clay.

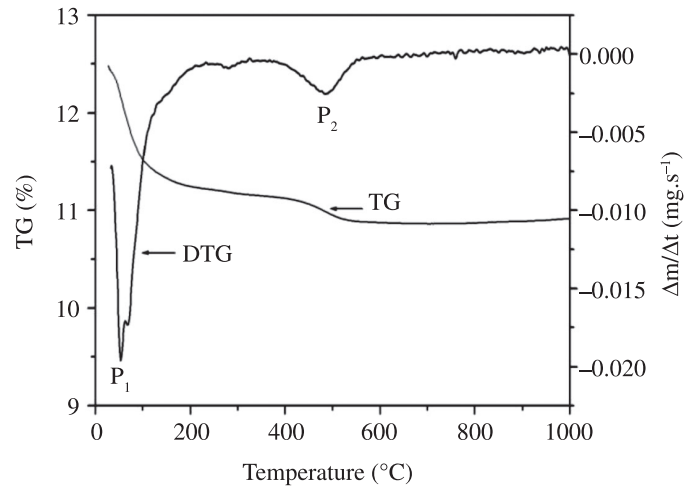

(a)

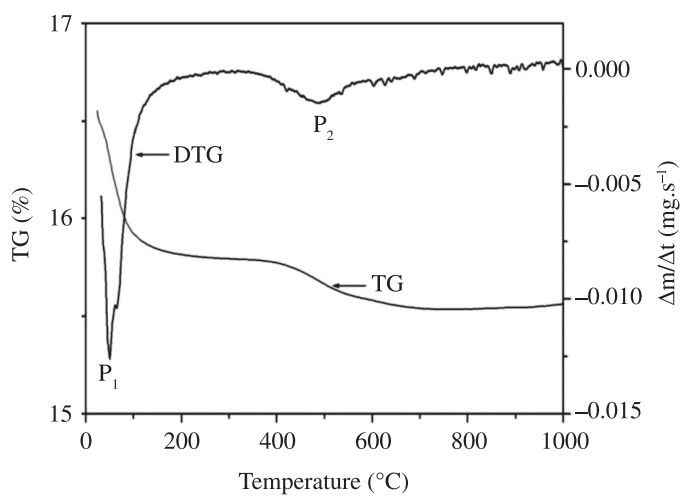

(b)

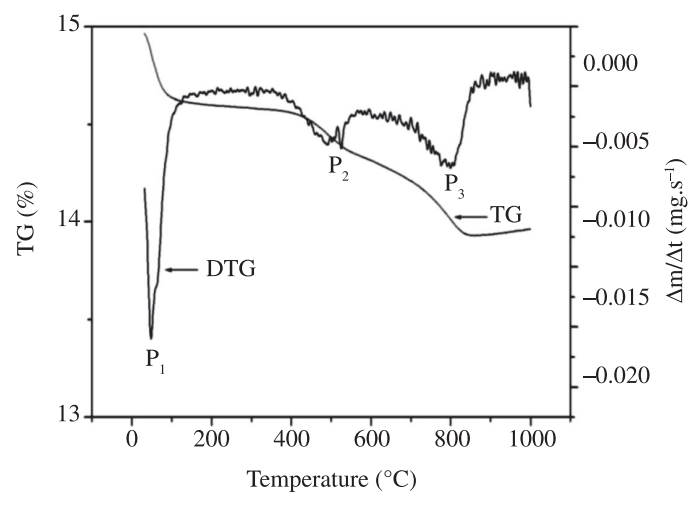

(c)

Figure 3. Thermogravimetric and its derivative curve for Bofe clay: (a) natural, (b) calcined and (c) sodium saturated clays. 
However, by the chemical speciation, at $\mathrm{pH}=5.0$ starts the precipitation of zinc. Thus, to ensure the adsorption process, the $\mathrm{pH}$ was set to 4.5 for all conditions studied.

The $\mathrm{pH}$ of the dispersion formed by natural, calcined and sodium saturated Bofe clays were measured, whereby $1 \mathrm{~g}$ of clay was dispersed in $100 \mathrm{~mL}$ of deionized water. The results were $\mathrm{pH}$ 7.7, 4.3 and 7.9 for natural, calcined and sodium saturated clays, respectively.

The $\mathrm{pH}$ of the clay results in part from the nature of exchangeable ions present. According to the chemical composition obtained by EDS (Table 1), the exchangeable ions of Bofe clays are alkali metal cations and alkaline earth metals, which give an alkaline $\mathrm{pH}$ to the dispersions formed by natural clays. With calcination, no loss of cations, but dehydroxylation occurs, which provides an acid $\mathrm{pH}$ for the dispersion formed with the calcined clay.

\subsection{Adsorption experiments}

\subsubsection{Adsorption kinetics}

The Figure 6 shows the kinetic curves for the adsorption capacity for $\mathrm{Zn}^{2+}$ ions fitted to models of pseudo-first order and pseudo-second order by natural (a), calcined (b) and

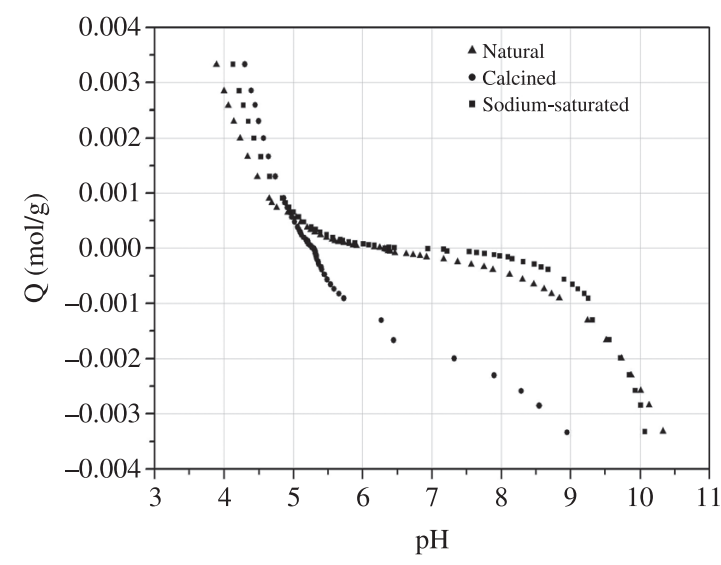

Figure 4. Potentiometric titration of natural, calcined and sodium saturated clays.

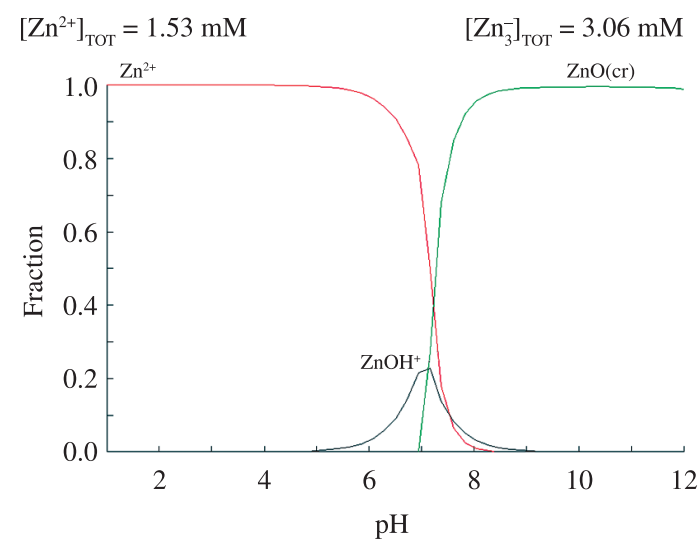

Figure 5. speciation curve of the $\mathrm{Zn}^{2+}$ ion in aqueous solution with nitrate ions at differents concentrations determined through the HYDRA application sodium saturated (c) Bofe clays. The intraparticle diffusion model was also fitted to the experimental data, however, it had no satisfactory results and the curves were not presented.

The parameters obtained from fitting of the pseudo-first, pseudo-second order and intraparticle diffusion models are listed in Table 3 . The value of $\mathrm{R}^{2}$ demonstrates that the pseudo-second order model best fitted the experimental results compared to the pseudo-first order model for all the clays analyzed in this study. The kinetic model of pseudo-second order assumes that the limiting step of the process is chemisorption involving valence forces by sharing or exchanging electrons between the adsorbent and the metal ${ }^{22}$.

The capacity of $\mathrm{Zn}^{2+}$ removal on sodium saturated Bofe clay increases, whereas in calcined clay, it decreases

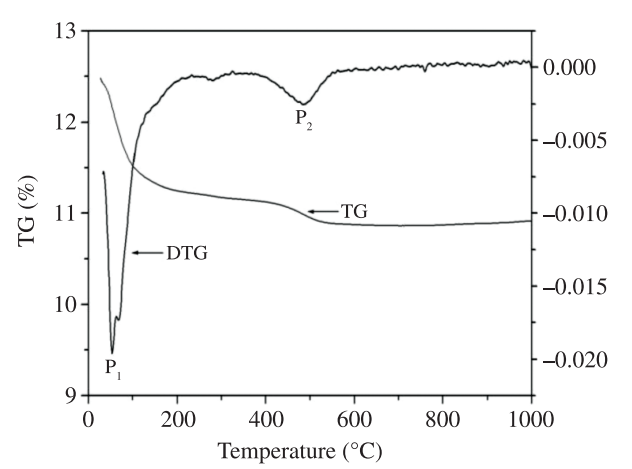

(a)

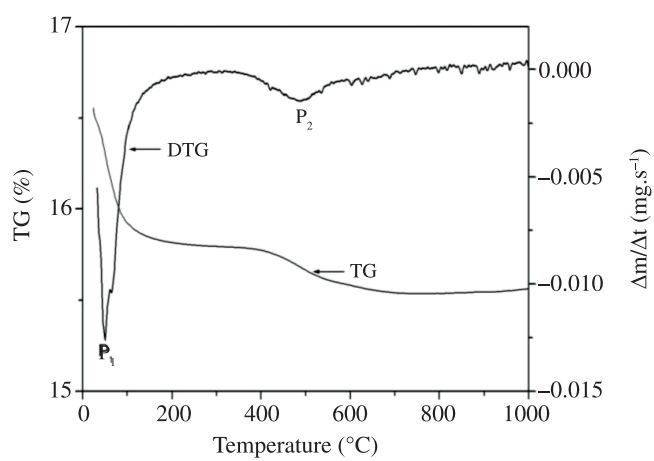

(b)

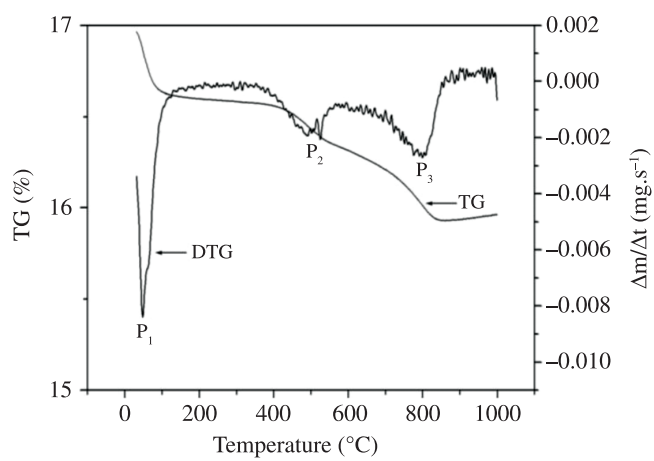

(c)

Figure 6. Kinetic curve for zinc adsorption fitted to pseudo-firstorder kinetic model and second-order kinetic model: (a) natural, (b) calcined and (c) sodium saturated clays. 
compared to natural Bofe clay (Table 3). However, the calcination of clay is necessary, since after this process the clay suffers dehydration and dehydroxylation, which cause changes in the structure so as it does not expand in water, making it favorable for the adsorption in fixed bed ${ }^{22}$. On the other hand, sodium treatment improved the adsorption capacity, easing the exchange of metal ions by sodium ions.

\subsubsection{Adsorption equilibrium}

The Figure 7 shows the adsorption isotherms of $\mathrm{Zn}^{2+}$ by calcined and sodium saturated Bofe clay fitted to models of Langmuir and Freundlich. The isotherms had a similar behavior, and both can be classified as favorable. Table 4 quotes the parameters obtained by these adjustments.

Observing the $\mathrm{R}^{2}$ values in Table 4 , the Langmuir model best fits the concentrations of $\mathrm{Zn}^{2+}$ adsorbed than Freundlich model. Similar results were found by Bhattacharyya and Gupta $^{23}$ for the removal of heavy metals on montmorillonite. The values for Freundlich constant is $0.2-0.3$ indicating that the adsorptive characteristics of calcined and sodium-saturated Bofe clays are good for zinc adsorption. The amount of metal adsorbed at equilibrium, adjusted by Langmuir model, was $0.13 \mathrm{mEq} . \mathrm{g}^{-1}$ and $0.24 \mathrm{mEq} . \mathrm{g}^{-1}$, for calcined and sodium saturated Bofe clays, respectively. The greater amount of metal adsorbed at equilibrium to the sodium saturated clay may be related to the phenomenon of ion exchange existing in this process, as with the use of $\mathrm{NaCl}$ is increased the number of cations $\mathrm{Na}^{+}$, which is more easily exchangeable by being monovalent, which are surrogate of zinc. Therefore, the model of pseudo-second order showed better agreement with the values obtained by Langmuir model.

To evaluate the affinity between adsorbate and adsorbent, the dimensionless separation factor $\left(R_{L}\right)$ was calculated, based on Langmuir constant $b$ and the initial zinc concentration presented in Table 5. The values of $\mathrm{R}_{\mathrm{L}}$ for zinc adsorption on calcined and sodium saturated Bofe clays range between 0 and 1 , characterizing a favorable adsorption, mainly for the highest initial concentrations of metal.

\subsubsection{Thermodynamic study}

The Figure 8 shows the isotherms of $\mathrm{Zn}^{2+}$ adsorption on calcined Bofe clays fitted with Langmuir models at $293 \mathrm{~K}$, $313 \mathrm{~K}, 323 \mathrm{~K}$ and $348 \mathrm{~K}$. For all temperatures, the isotherms had the same behavior and are classified as favorable.

Table 3. $\mathrm{Zn}^{2+}$ adsorption rate coefficients for pseudo-first-order and pseudo-second-order on Bofe clay.

\begin{tabular}{|c|c|c|c|c|c|c|}
\hline \multirow[t]{2}{*}{ Bofe clay } & \multicolumn{3}{|c|}{ Pseudo-first-order } & \multicolumn{3}{|c|}{ Pseudo-second-order } \\
\hline & $\mathrm{q}_{\mathrm{m}}\left(\mathrm{mg} \mathrm{g}^{-1}\right)$ & $a_{1}\left(\min ^{-1}\right)$ & $\mathbf{R}^{2}$ & $\mathrm{q}_{\mathrm{m}}\left(\mathrm{mg} \cdot \mathrm{g}^{-1}\right)$ & $a_{2}\left(g \cdot \mathrm{mg}^{-1} \cdot \mathrm{min}^{-1}\right)$ & $\mathbf{R}^{2}$ \\
\hline natural & 6,899 & 0.787 & 0.927 & 7.135 & 0.152 & 0.981 \\
\hline calcined & 4.648 & 0.677 & 0.951 & 4.799 & 0.214 & 0.991 \\
\hline Sodium saturated & 8.067 & 0.819 & 0.963 & 8.296 & 0.151 & 0.994 \\
\hline
\end{tabular}

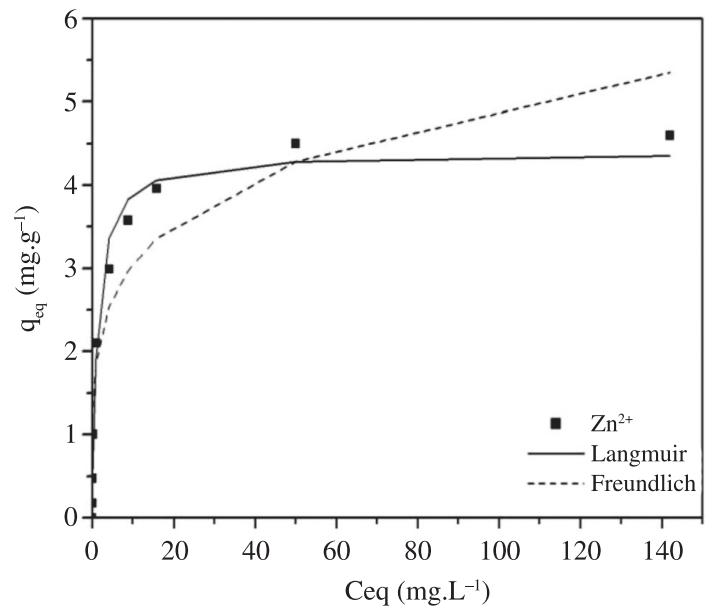

(a)

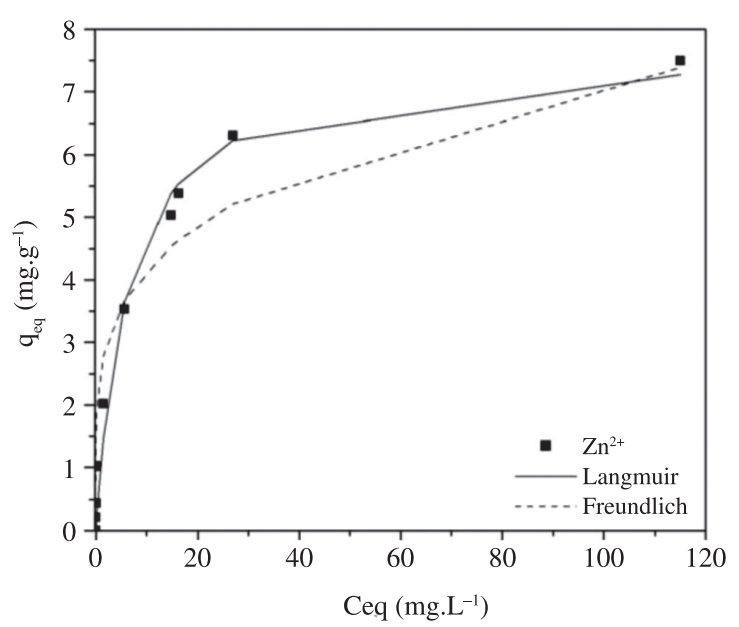

(b)

Figure 7. Adsorption isotherms adjusted to the models of Langmuir and Freundlich: (a) calcined and (b) sodium saturated clays.

Table 4. Ion $\mathrm{Zn}^{2+}$ parameters obtained by fitting the model of Langmuir and Freundlich.

\begin{tabular}{|c|c|c|c|c|c|c|}
\hline \multirow[t]{2}{*}{ Bofe clay } & \multicolumn{3}{|c|}{ Langmuir } & \multicolumn{3}{|c|}{ Freundlich } \\
\hline & $\mathbf{q}_{\mathrm{m}}\left(\mathrm{mg} \mathrm{g}^{-1}\right)$ & b $\left(\right.$ L. $\left.\mathrm{mg}^{-1}\right)$ & $\mathbf{R}^{2}$ & $k_{f}\left(L \cdot g^{-1}\right)$ & $\mathbf{N}$ & $\mathbf{R}^{2}$ \\
\hline calcined & 4.395 & 0.767 & 0.9822 & 18.663 & 0.213 & 0.9459 \\
\hline Sodium saturated & 7.967 & 0.161 & 0.9817 & 17.909 & 0.276 & 0.9709 \\
\hline
\end{tabular}




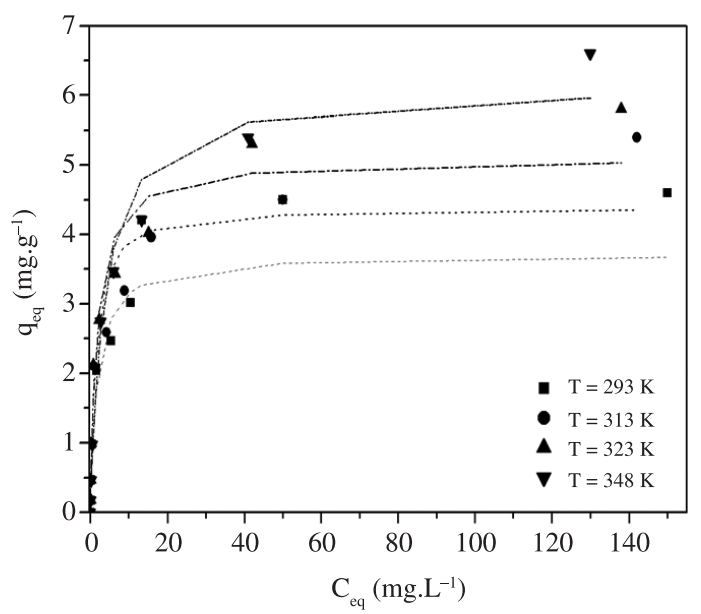

Figure 8. Isotherms of $\mathrm{Zn}^{2+}$ adsorption on calcined Bofe clay fitted to Langmuir models at $293 \mathrm{~K}, 313 \mathrm{~K}, 323 \mathrm{~K}$ and $348 \mathrm{~K}$.

Table 5. Separation factor values $\left(\mathrm{R}_{\mathrm{L}}\right)$ for $\mathrm{Zn}^{2+}$ adsorption by Bofe clay.

\begin{tabular}{ccccc}
\hline \multicolumn{2}{c}{ Bofe calcined } & & \multicolumn{2}{c}{ Bofe sodium saturated } \\
\cline { 1 - 2 } \cline { 5 - 5 } $\mathbf{C}_{\mathbf{0}}$ & $\mathbf{R}_{\mathbf{L}}$ & & $\mathbf{C}_{\mathbf{0}}$ & $\mathbf{R}_{\mathbf{L}}$ \\
\hline 1.92 & 0.41 & & 2.1 & 0.75 \\
4.9 & 0.21 & & 4.5 & 0.58 \\
10.2 & 0.11 & & 10.4 & 0.38 \\
22 & 0.06 & & 21.7 & 0.22 \\
34.1 & 0.04 & & 41 & 0.13 \\
44.7 & 0.03 & & 65 & 0.09 \\
55.5 & 0.03 & & 70 & 0.08 \\
95 & 0.01 & & 90 & 0.06 \\
188 & 0.01 & 190 & 0.03 \\
\hline
\end{tabular}

Moreover, the maximum capacity adsorbed increases with the increase of the temperature of the process, indicating that the energy increase favors the removal of zinc on the clay surface, and this can be attributed to the fact that by increasing temperature of the solution, the mobility of molecules also increases and, therefore, easing the diffusion of $\mathrm{Zn}^{2+}$ in the clay. Kubilay et al. ${ }^{6}$ performed experiments of zinc adsorption on bentonite clay and observed the same trend, i.e., as the temperature increases, the amount of adsorbed ion also increases. Table 6 lists the parameters obtained from these adjustments.

To verify the effect of temperature on zinc adsorption by calcined Bofe clay, the thermodynamic parameters enthalpy $(\Delta \mathrm{H})$, entropy $(\Delta \mathrm{S})$ and Gibbs free energy $(\Delta \mathrm{G})$ were calculated and presented in Table 7.

The negative value and the value lower than $40 \mathrm{~kJ}^{\mathrm{m}} \mathrm{mol}^{-1}$ of $\Delta \mathrm{H}$ indicate that $\mathrm{Zn}^{2+}$ adsorption on calcined Bofe clay is an isothermal process throughout the temperature range studied and of physical nature (physisorption), with weak Van der Waals bonds between $\mathrm{Zn}^{2+}$ and clay (Table 7).
Table 6. $\mathrm{Zn}^{2+}$ ion parameters obtained by fitting the Langmuir model.

\begin{tabular}{|c|c|c|c|}
\hline \multirow[b]{2}{*}{$\mathbf{T}(\mathbf{K})$} & \multicolumn{3}{|c|}{ Langmuir model } \\
\hline & $q_{m}\left(m_{g} \cdot g^{-1}\right)$ & b $\left(\mathbf{L} \cdot \mathbf{m g}^{-1}\right)$ & $\mathbf{R}^{2}$ \\
\hline 273 & 3.716 & 0.549 & 0.9648 \\
\hline 298 & 4.304 & 0.767 & 0.9822 \\
\hline 323 & 5.098 & 0.548 & 0.9652 \\
\hline 348 & 6.137 & 0.268 & 0.9715 \\
\hline
\end{tabular}

Table 7. Thermodynamic parameters of adsorption of $\mathrm{Zn}^{2+}$.

\begin{tabular}{cccccc}
\hline & & \multicolumn{3}{c}{ Langmuir model } \\
\cline { 1 - 3 } \cline { 5 - 6 } $\mathbf{T}$ & $\mathbf{k}_{\mathbf{d}}$ & & $\Delta \mathbf{G}$ & $\Delta \mathbf{H}$ & $\Delta \mathbf{S}$ \\
$(\mathbf{K})$ & $\left(\mathbf{L . g}^{-1}\right)$ & & -1.99 & -5.13 \\
\hline 273 & 1.225 & & -460.87 & & \\
298 & 1.286 & & -624.38 & & \\
323 & 1.677 & -1388.67 & & \\
348 & 1.755 & -1628.57 & & \\
\hline
\end{tabular}

Negative values of $\Delta S$ suggest a reduced randomness in the solid-solution interface during the adsorption of $\mathrm{Zn}^{2+}$ on calcined Bofe clay. For all temperatures studied, the negative values of $\Delta \mathrm{G}$ indicate that, thermodynamically, there was a decrease in Gibbs free energy confirming the viability of the adsorption process and that the clay- $\mathrm{Zn}^{2+}$ interactions took place spontaneously. Another aspect is that the variation of Gibbs free energy decreased with the temperature increase, pointing out that the adsorption process is more favorable at high temperatures. These results are in agreement with that obtained by Kubilay et al. ${ }^{6}$ in adsorption experiments for the removal of $\mathrm{Zn}^{2+}$ on bentonite clay between 293 and $353 \mathrm{~K}$.

\section{Conclusion}

Calcined and sodium saturated Bofe clays presented an adequate capacity of $\mathrm{Zn}^{2+}$ adsorption in aqueous solution, under the studied conditions. The characterization evidenced the changes occurred in the clays after treatment. Although with less capacity for zinc removal, the calcined clay is more suitable to be employed in fixed bed column, due to the stability gained from the thermal treatment. The pseudo-second-order kinetic model best represented the mechanism of interactions involved during the adsorption. The experimental data at equilibrium satisfactorily fitted the Langmuir model. These results show that calcined and sodium-saturated Bofe clays may be used for elimination of $\mathrm{Zn}^{2+}$ through adsorption mechanisms and can replace other adsorbents more expensive, because of high availability, low cost, even after the treatments, and good adsorption properties.

\section{Acknowledgements}

The authors acknowledge to CNPq, CAPES and FAPESP for financial support. 


\section{References}

1. Toor M and Jin B. Adsorption characteristics, isotherm, kinetics, and diffusion of modified natural bentonite for removing diazo dye. Chemical Engineering Journal. 2012; 187:79-88. http:// dx.doi.org/10.1016/j.cej.2012.01.089

2. Parolo ME, Avena MJ, Pettinari GR and Baschini MT. Influence of $\mathrm{Ca}^{2+}$ on tetracyline adsorption on montmorillonite. Journal of Colloid and Interface Science. 2012; 368:420-426. PMid:22189389. http://dx.doi.org/10.1016/j.jcis.2011.10.079

3. Ghorbel-Abid I, Galai K and Trabelsi-Ayadi M. Retention of chromium (III) and cadmium (II) from aqueous solution by illitic clay as a low-cost adsorbent. Desalination. 2010; 256:190-195. http://dx.doi.org/10.1016/j.desal.2009.06.079

4. Jiang MQ, Jin XQ and Chen ZL. Adsorption of $\mathrm{Pb}$ (II), $\mathrm{Cd}$ (II), Ni (II) and $\mathrm{Cu}$ (II) onto natural kaolinite clay. Desalination. 2010; 252:33-39. http://dx.doi.org/10.1016/j. desal.2009.11.005

5. Arias F and Sen TK. Removal of zinc metal ion ( $\mathrm{Zn} 2+)$ from its aqueous solution by kaolin clay mineral: A kinetic and equilibrium study. Colloids and Surfaces A: Physicochemical and Engineering Aspects. 2009; 48:100-108. http://dx.doi. org/10.1016/j.colsurfa.2009.06.036

6. Kubilay S, Gürkan R, Savran A and Sahan A. Removal of $\mathrm{Cu}(\mathrm{II}), \mathrm{Zn}$ (II) and $\mathrm{Co}$ (II) ions from aqueous solutions by adsorption onto natural bentonite. Adsorption. 2007; 13:41-51. http://dx.doi.org/10.1007/s10450-007-9003-y

7. Veli S and Alyüz B. Adsorption of copper and zinc from aqueous solutions by using natural clay. Journal of Hazardous Materials. 2007; 149:226-233. PMid:17560022. http://dx.doi. org/10.1016/j.jhazmat.2007.04.109

8. Abollino O, Giacomino A, Malandrino M and Mentasti E. Interaction of metal íons with montmorillonite and vermiculite. Applied Clay Science. 2008; 227-236. http:// dx.doi.org/10.1016/j.clay.2007.04.002

9. Tito GA, Chaves LHG, Ribeiro S and Souza, RS. Isotermas de adsorção de cobre por bentonita. Revista Caatinga. 2008; 21(3):16-21.

10. Santos PS. Ciência e tecnologia de argilas. São Paulo: Edgard Blücher Ltda.; 1992.

11. Guarino AWS, San Gil RAS, Polivanov and Menezes HSMC. Characterization of a Brazilian Smectite by Solid State NMR and X-Ray Diffraction Techniques. Journal of the Brazilian Chemical Society. 1997; 8(6):581-586. http://dx.doi. org/10.1590/S0103-50531997000600004
12. Stumm W. Chemistry of the Solid-Water Interface. Nova York, John Wiley \& Sons; 1992.

13. Akar ST, Akar T, Kaynak Z, Anilan B, Cabuk A, Tabak Ö et al. Removal copper (II) ions from synthetic and real wastewater by the combined action of dried Trametes versicolor cells and montmorillonite. Hydrometallurgy. 2010; 97:98-104. http:// dx.doi.org/10.1016/j.hydromet.2009.01.009

14. Šljivić M, Smičiklas I, Pejanović S and Plećaš I. Comparative study of $\mathrm{Cu}^{2+}$ adsorption on a zeolite, a clay and a diatomite from Serbia. Applied Clay Science. 2009; 43:33-40. http:// dx.doi.org/10.1016/j.clay.2008.07.009

15. Özdemir G and Yapar S. Adsorption and desorption behavior of copper ions on Na-montmorillonite: Effect of rhamnolipids and pH. Journal of Hazardous Materials. 2009; 166:1307-1313. PMid:19178999. http://dx.doi.org/10.1016/j. jhazmat.2008.12.059

16. Bhattacharyya KG and Gupta SS. Adsorption of a few heavy metals on natural and modified kaolinite and montmorillonite: A review. Advances in Colloid and Interface Science. 2008; 140:114-131. PMid:18319190. http://dx.doi. org/10.1016/j.cis.2007.12.008

17. Ayari F, Srasra E and Trabelsi-Ayadi M. Characterization of bentonitic clays and their use as adsorbent. Desalination. 2005; 185:391-397. http://dx.doi.org/10.1016/j. desal.2005.04.046

18. Bojemueller E, Nennemann A and Lagaly G. Enhanced pesticide adsorption by thermally modified bentonites. Applied Clay Science. 2001; 18:277-284. http://dx.doi.org/10.1016/ S0169-1317(01)00027-8

19. Brindley GW and Brown G. Crystal structures of clay minerals and their X-ray identification. London: Mineralogical Society; 1980.

20. Santos PS. Tecnologia de argilas: aplicada às argilas brasileiras. São Paulo: Edgard Blücher Ltda.; 1975.

21. Ho YS and McKay G. The kinetics of sorption of divalent metal ions onto sphagnum moss peat. Water Research. 2000; 34:735-742. http://dx.doi.org/10.1016/S00431354(99)00232-8

22. Treybal RE. Mass transfert operations. 3rd ed. New York: McGraw Hill; 1980

23. Bhattacharyya KG and Gupta SS. Adsorptive accumulation of $\mathrm{Cd}(\mathrm{II}), \mathrm{Co}(\mathrm{II}), \mathrm{Cu}(\mathrm{II}), \mathrm{Pb}(\mathrm{II})$, and $\mathrm{Ni}(\mathrm{II})$ from water on montmorillonite: Influence of acid activation. Journal of Colloid and Interface Science. 2007; 310:411-424. PMid:17368467. http://dx.doi.org/10.1016/j.jcis.2007.01.080 